\title{
Political Violence and Unemployment: Socio-Economic Strain as a Potential Source of Terrorism
}

\author{
Reinmar C. Freis-Beattie \\ West Virginia University
}

Follow this and additional works at: https://researchrepository.wvu.edu/etd

\section{Recommended Citation}

Freis-Beattie, Reinmar C., "Political Violence and Unemployment: Socio-Economic Strain as a Potential Source of Terrorism" (2013). Graduate Theses, Dissertations, and Problem Reports. 423.

https://researchrepository.wvu.edu/etd/423

This Thesis is protected by copyright and/or related rights. It has been brought to you by the The Research Repository @ WVU with permission from the rights-holder(s). You are free to use this Thesis in any way that is permitted by the copyright and related rights legislation that applies to your use. For other uses you must obtain permission from the rights-holder(s) directly, unless additional rights are indicated by a Creative Commons license in the record and/ or on the work itself. This Thesis has been accepted for inclusion in WVU Graduate Theses, Dissertations, and Problem Reports collection by an authorized administrator of The Research Repository @ WVU. For more information, please contact researchrepository@mail.wvu.edu. 
Political Violence and Unemployment: Socio-Economic Strain as a Potential Source of Terrorism

\author{
Reinmar C. Freis-Beattie
}

\begin{abstract}
Thesis submitted to the
Eberly College of Arts and Sciences

at West Virginia University

in partial fulfillment of the requirements

for the degree of
\end{abstract}

Master of Arts

in

Sociology
Lisa Dilks, PhD., Chair
Jason Manning, PhD.
Joshua Woods, PhD.

Division of Sociology and Anthropology

Morgantown, West Virginia

2013

Keywords: Domestic Terrorism, General Strain Theory, Negative Emotions, Crime and Conflict 


\section{ABSTRACT \\ Political Violence and Unemployment: Socio-Economic Strain as a Potential Source of Terrorism}

\section{Reinmar Freis-Beattie}

Why do some people commit acts of violence which are politically or ideologically motivated? Furthermore, why does the United States see such great variation in the number of terrorist incidents from year to year? To help answer these questions, Robert Agnew's (2010) General Strain Theory of Terrorism lays out a foundational model to explain what might cause terrorism. In contrast to previous strain theories, General Strain Theory of Terrorism argues that the strains most likely to result in terrorism are collective strains which are (a) high in magnitude, with civilians affected; (b) perceived as unjust; and (c) inflicted by more powerful 'others'. Collective strains affect groups or entire societies, rather than specific individuals. Collective strains increase negative emotions and attitudes, radicalize groups and individuals, contribute to a collective orientation and response, and facilitate the social learning of terrorism, while also reducing social control and access to legal coping means.

To test this theory, I argue that economic strains constitute collective strains. From this point I tested a portion of GST, focusing my analysis within the US, and examining the conduit from economic strain to increasing negative emotions to domestic terrorism using a path analysis of macro-level data collected from public sources. The analysis showed moderate support for theoretical assumptions. Some macroeconomic indicators such as unemployment can lead to domestic terrorism, while others such as poverty do not. As unemployment in the US rises, so do negative emotions and attitudes, and through this, incidents of domestic terrorism. Of course, economic factors are only one possible source of strain, and negative emotions are only one mediator in Agnew's model. From this we can conclude that General Strain Theory of Terrorism may be a worthwhile avenue for future research. 


\section{ACKNOWLEDGEMENTS}

I would like to thank my thesis chair, Lisa Dilks, for all the help she provided in making this thesis possible. I would also like to thank my committee members, Jason Manning and Joshua Woods, for their comments and constructive influence. In addition, I would like to acknowledge the support which I have received from my family, friends, and colleagues. All were extremely helpful in developing this work. 


\section{TABLE OF CONTENTS}

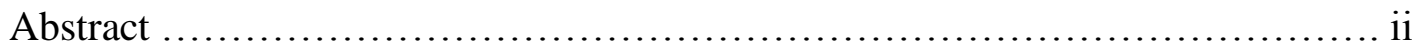

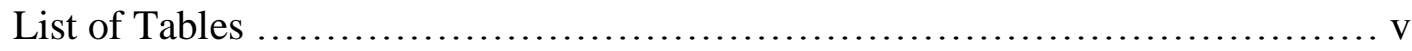

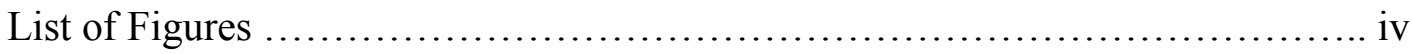

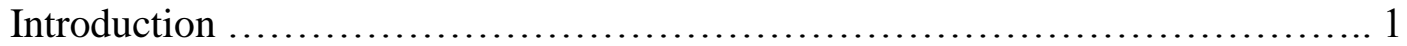

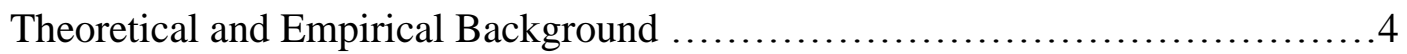

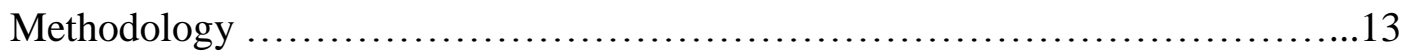

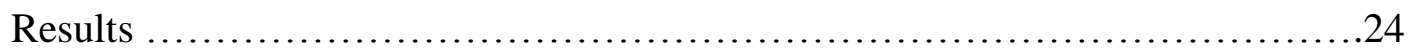

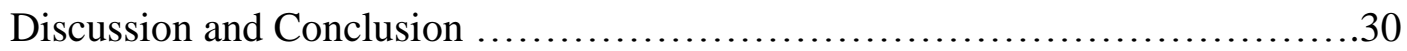

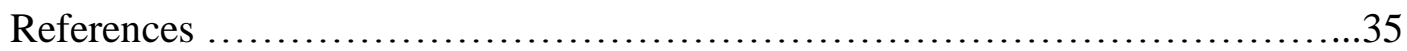

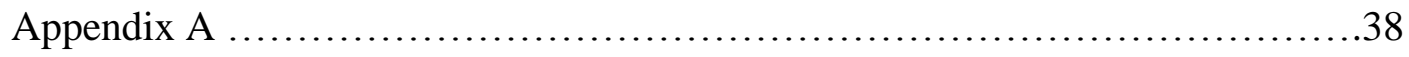

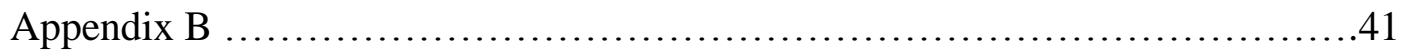




\section{LIST OF TABLES}

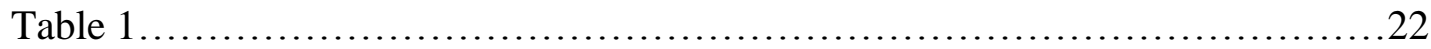

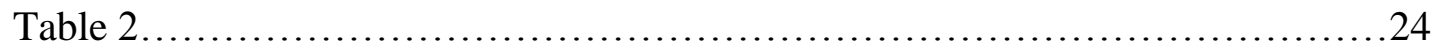

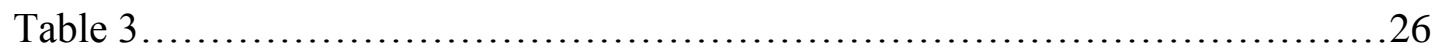

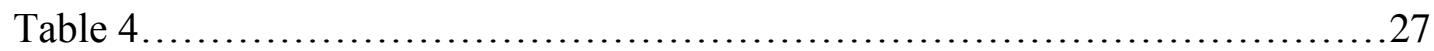

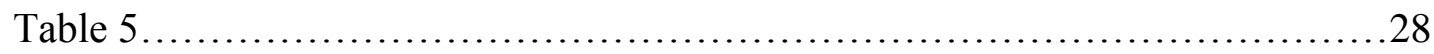

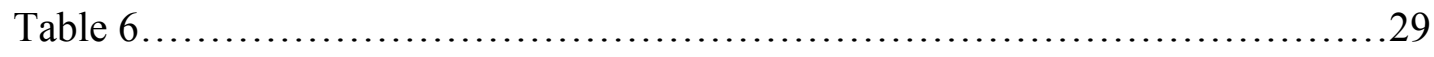




\section{LIST OF FIGURES}

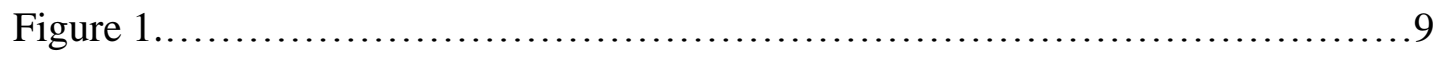

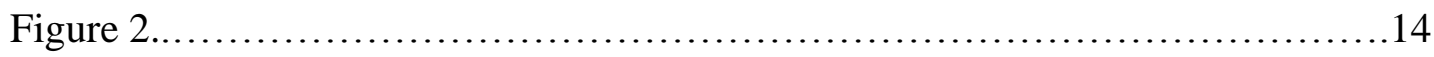

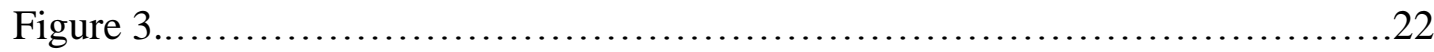

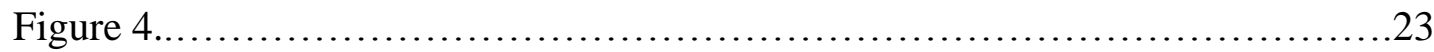

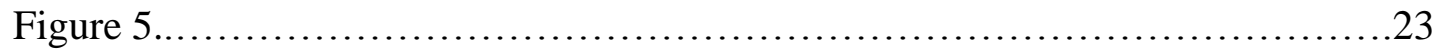

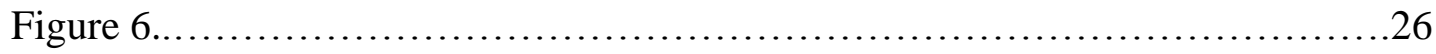




\section{INTRODUCTION}

Although it started out like any other Wednesday, April 19, 1995 would soon become one of the most tragic days in American history. On that fateful day at 9:00am Central Time a massive explosion from a 4,800 pound bomb inside a Ryder truck ripped through the Alfred P. Murrah Federal Building in Oklahoma City, killing 168 people and wounding almost 700 more (Sofer 2012). The explosion was so massive that it damaged buildings within a 16 block radius, and until the attacks of September $11^{\text {th }}, 2001$, was the most violent terrorist incident to ever strike US soil. The attacker, Timothy McVeigh, was a white supremacist who believed that the Federal government was attacking the civil liberties of people like him and that a race war was on the horizon. Oklahoma City was certainly the most dramatic event of domestic terrorism in the United States, but tragic events like this occur more often than we would care to admit, and there never seems to be a consensus as to the rhyme or reason.

Every year, acts of violence occur in the United States which are distinct from traditional crimes. Acts of terrorism such as these are broadly defined as politically and socially motivated acts of violence which frequently target civilians or symbols of the US government. In recent decades, and especially since the events of September 11, 2001, terrorism has become a hotbutton issue in world politics and the results affect our daily lives. Though catastrophic events such as 9/11 or the Oklahoma City bombing stand out most in the media, in reality terrorism is much closer than we realize, often occurring as small-scale events orchestrated and carried out by US citizens. The bigger terrorist threat to the United States comes from within, rather than from an external aggressor. According to the FBI, between 1980-2001 about two-thirds of all terrorist plots were classified as "domestic", and that figure rose to 95\% between 2002 and 2005 
(FBI 2005). Understanding and solving the social problems of terrorism and political violence has become a top priority of both governments and scholars.

While the root causes of terrorism are controversially debated, one of the more popular ideas suggests that socio-economic strain may be a contributing factor. An unclassified Department of Homeland Security (DHS) report from April 2009 predicted an increase in domestic terrorism citing the economic climate, high unemployment, mortgage foreclosures, and many returning military veterans as likely influences. This report draws many of its conclusions based on perceived similarities to the years leading up to the Oklahoma City bombing (DHS 2009).

The goal of this research is to evaluate the validity of the relationship between economic strain and terrorism. Some scholars conceptualize strain as pressure or stress exerted on an individual from an external force, which provoke individuals to engage in certain deviant behaviors (Agnew 1938). Robert Agnew (1992) described strain as "relationships where others are not treating the individual as he or she would like to be treated (p.48)." Within this definition, strain can be interpreted as an event, an interpretation of stimuli, and emotional responses. In terrorism research, strain is frequently used synonymously with 'grievances' (Agnew 2010). Economic strain is, therefore, strain or grievances which result from economic conditions or forces.

Specifically, I examine this relationship under the framework of Agnew's General Strain Theory of Terrorism (2010). Agnew's theory focuses on how collective strains influence terrorist type behaviors, laying out the specific conditions or "paths" that lead to terrorism, such as radicalization, reduced social control, and increased negative emotions. Testing all the possible "paths" to terrorism is beyond the scope of this thesis. Instead, I focus specifically on the role of negative emotions and attitudes and in connection to economic strains to subsequent terrorist 
acts. I utilize data from the Global Terrorism Database, Stimson's Public Mood Variable, Gallup's Most Important Problem, the US Census Bureau, and Bureau of Labor Statistics to assess the validity of a path model connecting economic strain, negative emotion, and terrorism.

Though many scholars have theorized about the possible causes of terrorism (Black 2004, Ehrlich and Liu 2002, Pape 2005, Sageman 2004, Schinkel 2009), currently there is little consensus among empirical studies evaluating the validity of theoretical work. Regarding the principles Robert Agnew's theory, the literature is divided in its attempts to evaluate these ideas, with some studies finding a relationship, and others unable to reveal any significant connection between economic deprivation and terrorism. At minimum, this study will attempt to add to the current body of research, by empirically evaluating a specific theoretical perspective.

On a more practical side, since terrorism and political violence are real-world problems taken seriously by policy makers, it is essential that the root causes are examined as closely as possible, as many anti-terrorism policies affect our daily lives. In the seemingly unending period of economic strain in which the US and much of the rest of the world is experiencing, it is also pertinent to evaluate whether or not we can predict if levels of politically motivated violence will rise. Since the onset of the economic recession in 2008 , the political climate in the US has steadily become more polarized and hostile. As unemployment has risen so have tempers, and the more radical voices in our system have moved themselves to center stage (Przybyla 2011). If the hypotheses presented in this research are correct, then policy makers should consider combatting economic strain to be of paramount importance in reducing and preventing political violence and terrorism within the United States. 


\section{ThEORETICAL AND EMPIRICAL BACKGROUND}

The terrorism literature is a huge body of both theoretical and empirical research which is growing rapidly. Searching Google Scholar for the word "terrorism" currently returns over 700,000 academic sources. However, the current body of research is divided regarding the possible root causes of terrorism and politically motivated violence. In this section, I attempt to address some of the prevalent ideas and prominent studies upon which this research is built.

\section{Theories of Terrorism}

Explanations of terrorism are as wide reaching as the social sciences will allow. Perspectives from every discipline exist, whether psychological, political, economic, or sociological. Some of the prominent and relative perspectives are discussed below.

An Identity Theory approach explaining religiously and ethnically motivated terrorism asserts that the interaction between cultural identity, social identity, and personal identity can be deterministic in whether an individual participates in terrorist activity (Schwartz, Dunkel, and Waterman, 2009). This approach focuses on terrorism more as a cultural phenomenon, namely when religious or ethnic groups such as Al Qaeda, the PLO, Chechen Rebels, and IRA engage in terrorist activities. However these ideas do not effectively explain cases of domestic terrorism in the United States. A similar, though more relevant theoretical approach, hypothesizes that group radicalization is a mechanism which can lead to terrorism (McCauley and Moskalenko, 2008). Under this pretense, terrorism is the outcome of a process of inter-group conflict.

The logic of framing terrorism through rational choice has been argued by multiple authors (Caplan 2006; Turk 2004). The rational choice model argues that terrorism is not a haphazard or indiscriminate phenomenon, but rather one of many means to a social or political end, and with 
potential risks and gains strategically calculated. In this framework terrorism is seen as a political act, used similarly to protests, voting behavior, and even warfare.

However, other scholars feel that the rational choice model, used primarily by political scientists and economists, is too narrow and simplistic (Schinkel 2004). Instead, this counterargument posits that the social and historical context of terrorism is more important to understanding the problem. Rationalism in this sense is better defined through the group rather than the individual, where the group seeks to maximize the effect of limited resources for social or political gain (Schinkel 2004). Essentially, when these perspectives are taken together, terrorism is not a random act, but one that is employed to achieve a goal. Therefore it should be at least somewhat predictable.

These perspectives are focused primarily on the choice of terrorism as a method to address grievances or accomplish a goal. Rather than evaluate the factors which shape the choice to employ one tactic over another, I instead seek to evaluate variables which shape the impetus of terrorism. What are the root causes which influence groups and individuals to become violent in the first place? To examine this aspect of terrorism, I turn to another school of thought that focuses on the role of structural variables and how such forces may "push" individuals and groups to turn to violence. This type of theoretical framework posits that political violence and terrorism in particular, are the result of broader socio-economic trends (Ehrlich and Liu 2002). Within this perspective, Social Strain Theory, which has its roots in Merton's Anomie Theory (1938) and later updated by Agnew's General Strain Theory (1992), offers an explanation of terrorism in the United States. 


\section{Social Strain Theories and Terrorism}

Originating in the structuralist perspective and continuing in the tradition of Durkheim (1895), strain theory approaches have traditionally been used by criminologists to explore the link between deviance and socio-economic disadvantage (Cohen 1965). The main principle in strain theory and its sub-theories is that structural, socio-economic factors put strain on individuals which "pushes" them into deviance (Merton 1938). Merton's Anomie Theory focused on the influence of roles, class, and cultural factors along with structural conditions, on individual deviance. Merton theorized that failure to achieve specified social goals, such as the acquisition of material wealth and status, produces strain on individuals. In order to cope with strain, individuals use legitimate or illegitimate means to accomplish these social objectives, or abandon these goals, or both in five different coping strategies: conformity, innovation, ritualism, retreatism, and rebellion.

Despite its popularity, Anomie Theory is not without its weaknesses. The primary shortcoming of the theory is that it focuses primarily on the acquisition of material wealth as the social goal. This approach fails to explain non-utilitarian, ideological, or malicious crimes which do not result in material gain (Cohen 1997). To address the problems with Merton's original idea, Agnew re-focused strain theory and asserted that strain could come from many places, focusing instead on norms, emotions, and the individual's immediate social environment (1992).

Agnew's General Strain Theory differs from Merton in a few key ways. Metron's Anomie Theory focuses on macro-level forces, while Agnew's theory focuses more on micro- level forces of social learning and immediate social environments. This refocusing and individualizing of strain from the macro- to micro-level is the primary contribution of General Strain Theory to the strain literature. In addition, Anomie Theory does not adequately address the role of emotion 
in crime (Agnew 1992; Cohen 1965), which Agnew sought to rectify with General Strain Theory, arguing that structure and the social environment pressure individuals to commit deviant acts with emotions as their primary mediator (Agnew 1992).

The same ideas about structure, strain, and social environment can be applied to terrorism, from the point of view that terrorism is a response to social and political grievances. The strain produced by structural and environmental factors pushes individuals and groups towards violence. These views have become popular enough that Agnew himself has proposed a “General Strain Theory of Terrorism" (GST) which offers a customized version of strain theory specifically for terrorism. The key difference between GST and other strain-based theories is that GST focuses on "collective strains", whereas other approaches focus on strains as perceived by individuals (Agnew 2010). In other words, in previous theories strain was conceptualized as something that is felt only by individuals (Merton 1938; Agnew 1992), GST emphasizes strain as something felt by groups, and societies as a whole, in addition to the strain felt by individuals (Agnew 2010). This idea of collective experience of strain is central to how strain can translate into terrorism under the GST framework. With GST, these ideas of structure, social control, and social environment are applicable to both the micro- and macro-levels, and encompass a much broader scope than either Anomie Theory or General Strain Theory, while staying focused on a particular social phenomena.

According to Agnew collective strains must be, "(a) high in magnitude, with civilians affected; (b) perceived as unjust; and (c) inflicted by significantly more powerful others, including 'complicit' civilians, with whom members of the strained collectivity have weak ties. (2010: 136)" He also argues that the likelihood of terrorism is amplified by these collective strains via increasing negative emotions, decreasing social control, diminishing ability to cope 
through legal means, the cultivation of the social learning of terrorism, and a contribution to a collective emphasis and reaction. In other words, the link between the source of the collective strain and terrorism is not a direct one but, rather it follows one or more indirect paths. In this model, strain is transferred to groups and individuals via the various paths, similar to how a Newton's cradle transfers energy across several spheres while only visibly affecting the ends. According to GST, terrorism can occur through any of the paths, however the likelihood of terrorism increases as multiple paths are engaged (Agnew 2010).

Under Agnew's model (2010), collective strains affect a group or entire society. As such, individuals experience the strain as it is diffused through the collective, meaning that although their lives may only be indirectly connected to or displaced by the strain, the effects are still felt as very real, even if only vicariously. Societal level strains still create a sense of fear, worry, anger, and frustration in individuals. For example, one must not become unemployed to be fearful, angry, or frustrated about a rise in unemployment. Seeing those around you experience strain, or hearing daily accounts of the effects of strain which exists on the collective level is enough to evoke these feelings in individuals.

GST also postulates that not all strains are felt in the same way, and that very few people respond to strain with violence. Individuals and groups experience radicalization, increased negative emotions, and a collective emphasis and reaction. At the same time, collective strains reduce social control, reduce legal coping means, and facilitate the social learning of terrorism. This particular mix of forces is, according to Agnew, most likely to result in terrorism (2010). Figure 1 plots the various paths to terrorism from collective strain in Agnew's GST model. 
Figure 1: Visual Conception of Agnew's (2010) General Strain Theory of Terrorism

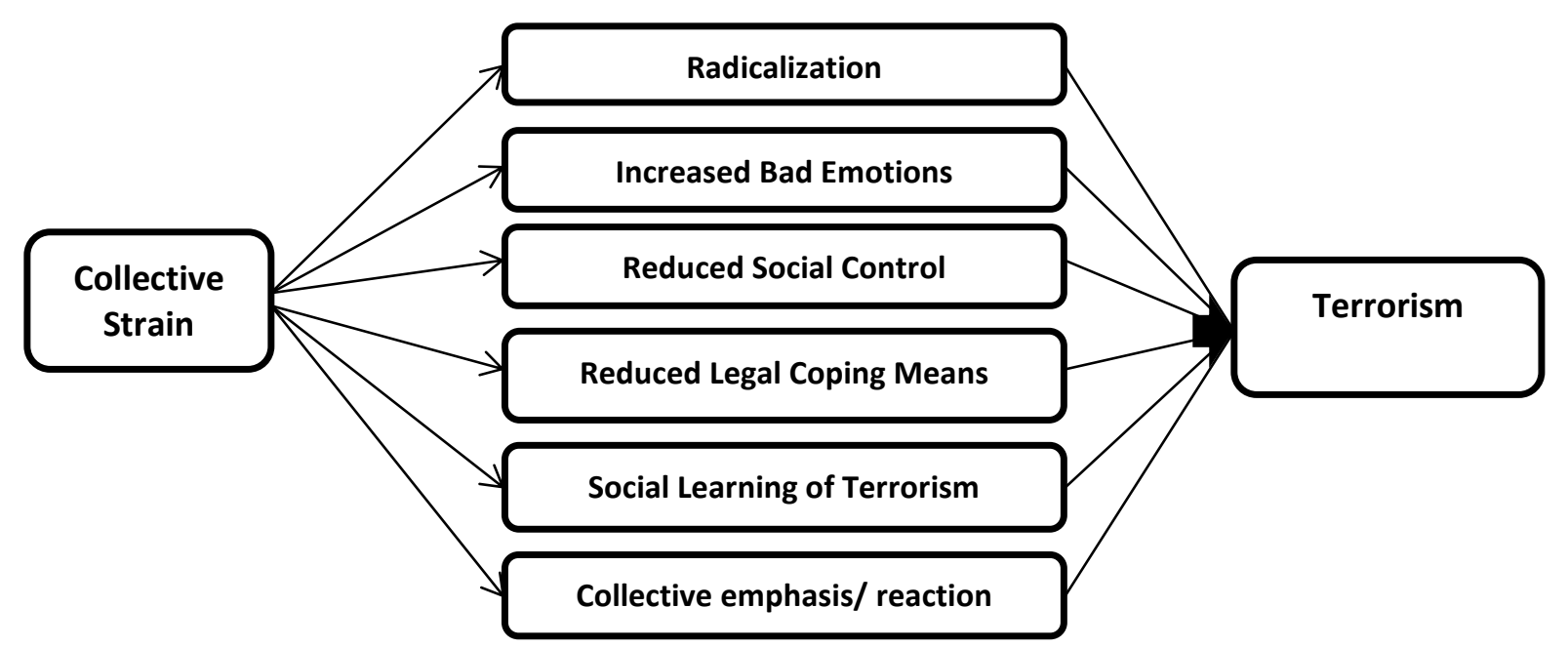

\section{Economic Conditions as Collective Strains}

In any empirical research, one of the biggest problems is translating abstract, theoretical concepts into concrete, operational variables that can be directly measured and tested. While the idea of collective strains is rather simple in itself, much of the work of operationalization has been left up to the researcher to define what constitutes a "collective strain." In addition, the task of operationalization also involves asking which collective strains are likely to result in terrorism. Furthermore, as of the final draft of this paper, no previous research exists that empirically evaluates GST. This lack of previous research exacerbates the challenge of operationalization of the model's key constructions but make the current research the first attempt to assess the validity and accuracy of Agnew's GST model (2010). 
In this paper I argue that economic strains, specifically those resulting from macroeconomic forces, constitute collective strains as defined by Agnew's criteria (2010). The economic atmosphere since 2008 is (a.) high in magnitude, affecting the entire country; (b.) perceived as unjust, especially with mass unemployment (Sanders, 2012); and (c.) inflicted by significantly more powerful "others", such as the Federal Government and Wall Street as well as specific politicians and bankers who, arguably, have weak ties to the collective (Gibbs 2009). From this perspective, I assert that economic strain produced from structural forces such as a bad economy and high unemployment affect attitudes at the group and individual levels. Individuals and groups affected are then affected through one or more of Agnew's "paths to terrorism" thereby increasing the likelihood of domestic political violence.

Although this research is the first to investigate the relationship between economic variables and terrorism under Agnew's GST framework, it is not the first to explore this connection between economic factors and terrorist acts. But these studies often yield contradictory results. Generally, studies of the relationship between economic variables and violence, including terrorism, use a frustration-aggression approach. Studies in this vein which focus on economic factors such as relative deprivation have been used to explain rebellions in the past (Gurr 1970). This approach, and others emphasizing the role of grievances, echoes many of the ideas found in the contemporary strain based approach to politically motivated violence.

For instance, Weeber and Rodahever (2003) used a content analysis of US militia movement web forum posts to determine whether social or economic strain was a precipitating factor in their membership rates. Their findings support the principles of Smesler's Theory of Collective Behavior, an earlier strain-based approach, and revealed that the majority of militia members 
experienced socio-economic strain before or during their membership (Weeber and Rodeheaver 2003).

A study by Burgoon (2006) argues that social welfare policies reduce incidents of international and domestic terrorism. The research hypothesizes that social welfare policies diminish support for terrorism by reducing contributing factors such as poverty, inequality, economic insecurity, and religious-political extremism, and that countries with higher social welfare spending will experience fewer domestic terrorist attacks and fewer of their citizens participate in terrorism as a result of this decrease in socio-economic strain. These hypotheses were supported by a regression analysis that examined terrorism and social welfare spending on a global scale with the country as the unit of analysis (Burgoon, 2006).

Another relevant article in support of the link between socio-economic factors and terrorism hypothesizes that countries with higher levels of minority discrimination will experience more incidents of domestic terrorism, and that more developed countries will experience lower levels of domestic terrorism (Piazza 2011). This study found that minority economic discrimination and general economic conditions were significant predictors of levels of domestic terrorism using a regression analysis (Piazza 2011). However, an earlier study by Piazza performed a crossnational analysis, but did not reveal any relationship between economic indicators and terrorism (Piazza 2006).

Another study using public opinion polls from the West Bank and Gaza Strip to analyze attitudes in support of terrorism did not find a reduction in support of terrorism among those with greater socio-economic resources (Krueger and Malekova, 2003). Krueger and Malekova (2003) also looked at Hezbollah's terrorist activities in Lebanon during the 1980s and 90s. This analysis 
did not reveal an empirical relationship between either economic factors or education and participation in terrorism.

Clearly, there is some contention as to what role economic strain plays in influencing terrorism and how influential it is. My project seeks to add this small but important piece to the literature on terrorism and economic strain in two ways: (1), empirically evaluating a portion of GST and (2) addressing some of the limitations in previous empirical research. Many of the studies also examined terrorism on a global level rather than within a specific country, which I believe weakens their results by failing to account for differences in social, political, and economic factors which vary greatly between countries. It is possible that economics may be a more powerful force of stain in some societies and irrelevant to terrorism in others. Also, most of these studies do not examine data over time but merely look at a snapshot of terrorist data. Since terrorism is a highly dynamic phenomenon, with levels of violence varying greatly from year to year and between regions, I believe that an approach which accounts for changes over time is necessary to explain how dynamic social, political, and economic forces can affect terrorism. 


\section{Methodology}

In this study, I perform a limited test of Agnew's GST model, focusing on how economic strains act as collective strains and affect negative emotions and attitudes, which in turn lead to acts of domestic terrorism. The rationale for this is twofold: First, as a relatively new theoretical model which is broad in scope, this paper takes a first step by evaluating GST by looking at a singular path to terrorism from collective strain. Second, a limited test will give an idea as to whether further and fuller tests of GST are worthwhile avenues to pursue with a larger. Since the theory is so broad, testing its individual parts is a logical first step.

While economic strains constitute the collective strain portion of this model, a key aspect to the GST paradigm is the role of intervening or amplifying conditions that lead from collective strains to terrorism. For this research I explore the pathway through negative emotions such as fear, anger, and frustration to terrorism. Due to the emphasis of the broader strain theory literature on the importance of emotions (Agnew 1992, 2010), I feel that this is an appropriate place to start when testing GST. In addition, research into emotion and political collective action has found that anger, contempt, and efficacy play a large role in participation (Van Zomeren et al. 2004) in contentious behavior. At this point, not much research has closely examined the role of emotions in terrorism; however there is a clear case that this is a worthwhile avenue of inquiry (Rice 2009). It is also important to note that while this study focuses on the impact of macroeconomic forces, strain can originate from any number of sources, and GST is a theory about how people react to the strains which they experience (Agnew 2010). Figure 2 illustrates the relevant path of GST that will be examined here. 


\section{Figure 2: Assessed Path of Agnew's (2010) General Strain Theory of Terrorism}

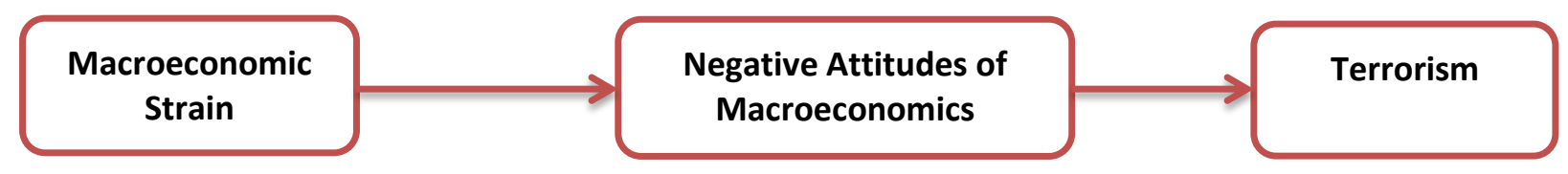

The theoretical pathway in Figure 2 translates into the following GST hypotheses:

Hypothesis 1: Increasing socio-economic strain will increase the level of negative emotions and attitudes in the United States.

Hypothesis 2: Increasing negative emotions and attitudes will lead to increased rates of domestic terrorist attacks in the United States.

\section{$\underline{\text { Data and Measures }}$}

This study utilizes secondary data analysis and examines data over time to evaluate the effect of dynamic change in socioeconomic factors on terrorist incidents. The unit of analysis is the nation-year, i.e. separate data for each variable organized by year (e.g. 1990, 1991, 1992, etc.). Since the root causes of terrorism and political violence have not yet proven to be generalizable across cultures, this model will have the most validity within the United States.

Testing the relationship between economic strain, negative emotions and attitudes, and terrorism in the United States is not a simple undertaking. Firstly, both strain and negative emotions and attitudes are latent variables. They are not directly measured, but rather constructed from different proxy measures. Secondly, since the link between collective strain and terrorism is not direct, a regression analysis is not sufficient to test the relationship. This project will therefore use a path analysis, a more appropriate method for testing Agnew's model. Primary 
hypotheses are derived from GST, and secondary hypotheses are derived from the individual measures used.

\section{Terrorism}

Terrorism is a controversial issue, and each agency, think tank, and group of scholars has their own unique definitional criteria. These are mostly similar definitions which are all equally vague in their parameters. Debating this however, is not the purpose of this research. For the purpose of this study, I rely on the Global Terrorism Database (GTD) definitional criteria for terrorism. It is a widely cited database, and considered by many to be the best source on terrorism in the United States.

The GTD defines terrorism as "The threatened or actual use of illegal force and violence by a non-state actor to attain a political, economic, religious, or social goal through fear, coercion, or intimidation." Within this blanket definition, the GTD also specifies that the act must be intentional, must involve some level of violence or threat of violence against persons or property, and that perpetrators must be sub-national actors (GTD Codebook). In addition, the GTD includes three criteria which can be required or not, allowing for researchers to specify the strictness of their definitions:

1. The act must be aimed at pursuing political, economic, religious, or social goal.

2. There must be evidence of an intention to coerce, intimidate, or convey some message to a larger audience than the immediate victims.

3. The action must be outside the context of legitimate warfare activities.

For this research, data was collected requiring all three criteria to be met for inclusion, giving us the strictest possible definition within the dataset. Incidents can also be filtered on many 
categories, such as geographic location, attack type, perpetrators, casualties, etc. and can be filtered on three specific definitional criteria, with unsuccessful attacks ambiguous cases either included or excluded. In addition, one further definitional criterion can be accounted for in the GTD: whether or not a sufficient doubt exists as to whether or not the event was exclusively terrorism. Many incidents of terrorism fall into a grey area with hate crime, insurgency, organized crime, and other crimes. This can be filtered out with the GTD's “Doubt Terrorism Proper" filter in the advanced search. This was also required in this research to filter ambiguous cases. Unsuccessful attacks were included as well, since the purpose of the project is to assess the likelihood that individuals or groups will use terrorism, not how successful they are.

This project also limits the number of terrorist incidents to those which fall into the classification of "Domestic" or "Homegrown" terror (Whitaker 2001), i.e. those committed by individuals who are US citizens either de jure or de facto. Definitional criteria for domestic or homegrown acts of terror were sourced from the FBI: "Domestic terrorism is the unlawful use, or threatened use, of force or violence by a group or individual based and operating entirely within the United States or Puerto Rico without foreign direction committed against persons or property to intimidate or coerce a government, the civilian population, or any segment thereof in furtherance of political or social objectives" (FBI 2005). Data was filtered to exclude incidents which did not meet either "domestic" or "homegrown" criteria. To be included in the analysis, groups must be based in the United States, and conduct their operations within the United States territory. Filtering was made on group affiliation, individuals and unknown perpetrators were included. A list of included and excluded groups is found in Appendix A.

In my analysis, the actual measure of terrorism used as the dependent variable is the total number of terrorist incidents committed and attempted within the United States by year, filtered 
using the aforementioned criteria. Recall that the goal is of course to assess the likelihood that individuals or groups turn to terrorism, not necessarily if they were successful. Once a count was made, years 1970 and 1971 were excluded as outliers, and 1993 is incomplete and counted as missing from the dataset, leaving 39 nation years for analysis.

\section{Independent Variables: Economic Strain}

My main independent variable of interest is economic strain, which I've chosen to measure with two indicators: unemployment rate, and poverty rate. I am primarily interested in the effect of the unemployment rate. Since unemployment is a highly dynamic force which rises and falls regularly, often translating into sudden shifts in socio-economic status for millions of individuals, I believe that it is most likely to create strain conditions which could result in terrorism. The unemployment rate is a measure of persons actively seeking gainful employment as a percentage of all workers in the United States. As defined by the Bureau of Labor Statistics, "Persons are classified as unemployed if they do not have a job, have actively looked for work in the prior 4 weeks, and are currently available for work. Persons who were not working and were waiting to be recalled to a job from which they had been temporarily laid off are also included as unemployed. Receiving benefits from the Unemployment Insurance (UI) program has no bearing on whether a person is classified as unemployed ${ }^{1} . "$

If socio-economic strain is a contributing factor to political violence, then unemployment should be a powerful predictor of terrorism in the United States. Unemployment is often a quickly changing force which has the potential to suddenly displace large numbers of people. Following from the frustration-aggression literature, these sudden drop offs in employment and

\footnotetext{
${ }^{1}$ Bureau of Labor Statistics. 2013. "Labor Force Characteristics." US Department of Labor http://www.bls.gov/cps/lfcharacteristics.htm\#unemp
} 
socioeconomic status are most likely to result in relative deprivation effects, which have shown to be a source of grievances in many political rebellions (Gurr 1970). This data was gathered from the Bureau of Labor Statistics, which allows public access of unemployment data specified by month and year.

Information on the yearly poverty rate is freely available from the Census Bureau. The poverty rate is calculated as a percentage of the population living under the legally defined poverty line by income ${ }^{2}$. Poverty is a likely source of strain for individuals, and the poverty rate is a dynamic variable. As Nathaniel Hawthorne once said, "Families are always rising and falling in America." Impoverished groups and individuals are likely to feel strains associated with their situations.

\section{Intervening Variables: Negative Emotions and Attitudes}

Agnew's model also specifies the importance of intervening variables, or variables which amplify the various "paths" to terrorism as outlined in his theory. Agnew outlines several ways that strain can lead to terrorism, such as increasing bad emotions, radicalization, reduced social control, diminished legal coping means, the social learning of terrorism, and orienting a population to a collective response (Agnew 2010). While testing all of these paths would be ideal, it is beyond the scope of this project. Instead, I focus on one which is particularly interesting to social psychologists: how negative emotions can lead to terrorism in the presence of strain. Negative emotions are also a latent construct, and since there is no direct measure, I again use proxies to gauge the extent of negative attitudes and emotions, particularly as they relate to economic conditions in the United States.

\footnotetext{
${ }^{2}$ More information about poverty rate statistics is available from the US Census Bureau http://www.census.gov/hhes/www/poverty/
} 
The first measure is from the Public Mood dataset, compiled by James Stimson ${ }^{3}$. The dataset aggregates public opinion surveys from 1952 until 2011 on a number of different topics and subtopics. For this analysis, I isolate the measure of public mood regarding macroeconomics, which I feel is most appropriate for assessing the relationship between economic mood and strain. Questions asked in the macroeconomic topic areas are typically based on a Likert Scale of strongly agree to agree or disagree to strongly disagree and cover a range of economic issues. Some sample questions asked include:

"Are you in favor of or against less government regulation of business?"

"Are you in favor of or against government financing of projects to create new jobs?"

"The government ought to see to it that every person who wants work has a job. Agree or disagree?”

"Do you feel rich people are asked to pay more than they should in federal income taxes, about the right amount, or less than they should?"

"I the government had to choose between keeping down inflation or keeping down unemployment, to which do you think it should give the highest priority?"

Public mood is measured on a scale of 1-100, with higher numbers associated with more liberalism, i.e. desire for more government involvement, openness to more spending (Stimson 2012). While this is a roundabout proxy measure, based on evidence from psychological research, we can expect that lower values or more conservative moods are associated with more negative emotions such as more resistance to change, and more extreme response to threats than higher or more liberalistic moods (Jost and Amodio 2011; Thorisdottir et al. 2007).

The second intervening variable used is Gallup's Most Important Problem, a collection of public opinion polls which assess the topic areas which are most important to Americans. The

\footnotetext{
${ }^{3}$ More information on Public Mood Data available from the Policy Agendas Project http://www.policyagendas.org/
} 
topic areas in the surveys are based on the topic areas used in the Public Moods dataset, and assess what percentage of people think that a given topic is the most important problem at the time. Once again, we used the Macroeconomic topic for our analysis. It is reasonable to think that when more people feel that macroeconomics is the most important problem that they experience more negative emotions, such as worry, fear, or anger, in relation to that topic. This variable is recorded as the percentage of respondents who feel that macroeconomic issues are the most important and pressing problems of the day.

\section{Operationalized Hypotheses}

Now that the dependent, independent, and intervening variables have been operationalized to measure terrorism, collective (economic) strain, and negative emotions and attitudes, respectively, I restate my hypotheses using these specific variables:

Hypothesis 1a: As the unemployment rate increases, macroeconomic public mood will decrease (i.e. become more negative).

Hypothesis 1b: As the unemployment rate increases, the percentage of Americans that view macroeconomics as the most important problem will increase.

Hypothesis 1c: As the poverty rate increases, macroeconomic public mood will decrease (i.e. become more negative).

Hypothesis 1d: As the poverty rate increases, the percentage of Americans that view macroeconomics as the most important problem will increase.

Hypothesis 2a: As macroeconomic public mood decreases (i.e. becomes more negative), the number of domestic terrorist attacks will increase.

Hypothesis 2b: As the percentage of Americans who view macroeconomic issues as the most important problem increases, the number of domestic terrorist attacks will increase. 


\section{Descriptive Statistics}

Table 1 lists basic descriptive information for the dependent, independent, and intervening variables used in the analysis. Figures 4 through 6 plot the change in the variables over the time period under analysis in this research (1972-2011, omitting 1993). From 1972 to 2011, the United States experienced an average of 32.5 incidents of domestic terrorism, with the largest year experiencing 112 incidents, and the lowest experiencing only 1 . Looking at economic indicators, unemployment averages $6.93 \%$ over the same period, ranging from $4.0 \%$ to $9.7 \%$, the poverty rate has an average of $13.1 \%$, with a range of $11.1 \%$ to $15.2 \%$. As far as emotions and attitude measures go, Public Mood averages a score of 59.08, ranging from 51.9 to 66.9, and Macroeconomics as the Most Important Problem has an average of 38.62\%, ranging between $11.45 \%$ and $78.78 \%$ from 1972 to 2011 . Looking at the variables graphed over time, we can see that they are dynamic phenomenon which can fluctuate greatly over time. Some do so more than others, for instance, terrorism and Most Important Problem have a large range of values, while unemployment, poverty, and public mood have more moderate variation. Terrorism peaks in the 1970s and 1980s, and has steadily declined from the late 1990s to the present. 
Table 1. Descriptive Statistics

\begin{tabular}{l|cccc} 
Variable & Mean & Standard Deviation & Minimum & Maximum \\
\hline Terrorism & 32.53 & 24.52 & 1 & 112 \\
Unemployment & 6.39 & 1.57 & 4.0 & 9.7 \\
Poverty & 13.1 & 1.23 & 11.1 & 15.2 \\
Public Mood & 59.08 & 3.78 & 51.9 & 66.9 \\
Most Important Problem & 38.62 & 16.98 & 11.45 & 78.78
\end{tabular}

Figure 3. Domestic Terrorist Incidents in the US

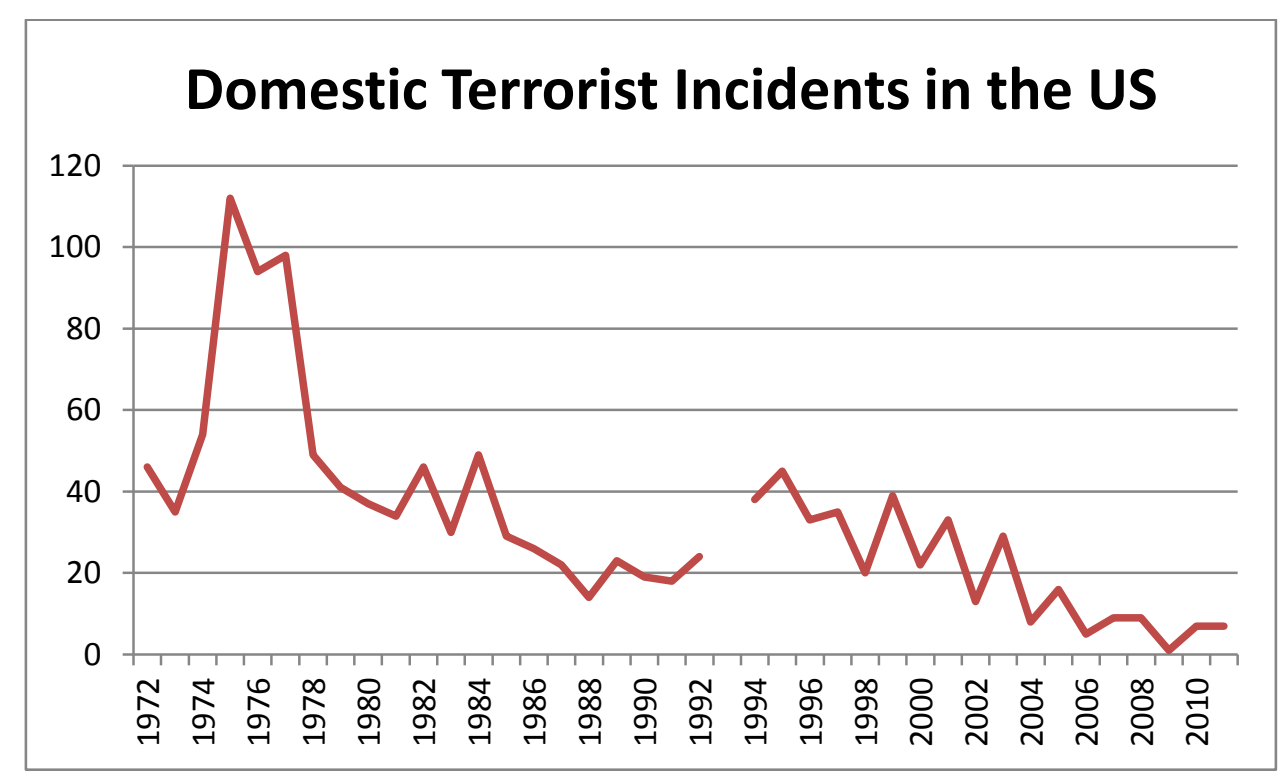


Figure 4. Economic Strain Variables

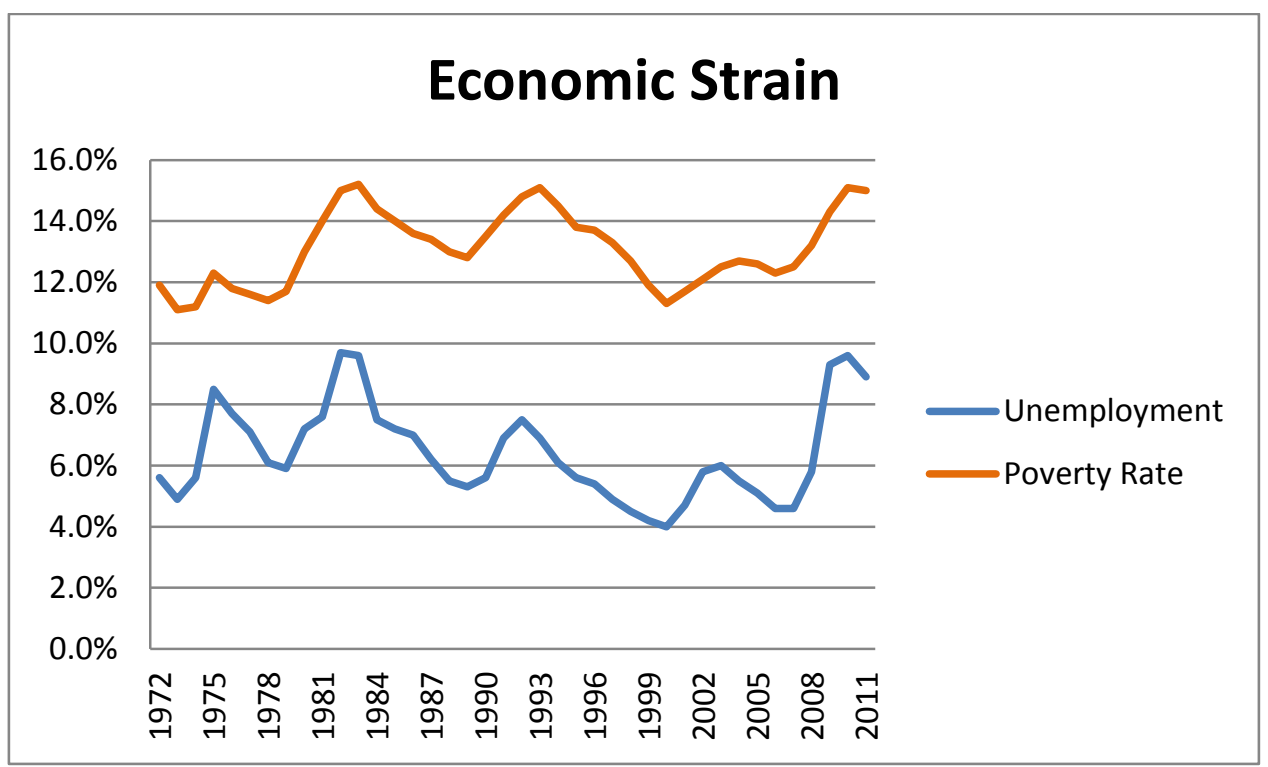

Figure 5. Emotions and Attitudes Variables

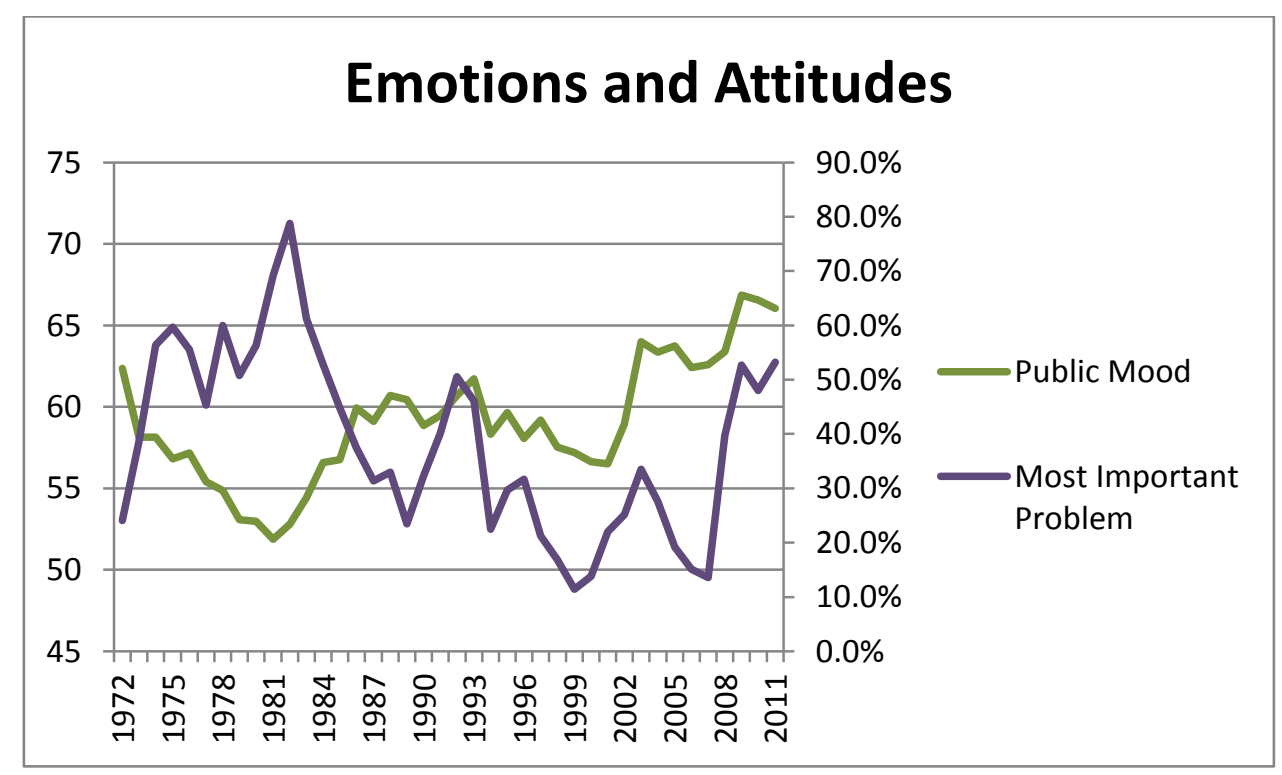




\section{Results}

Testing the relationship between economic strain, negative emotions and attitudes, and terrorism in the United States is not a simple undertaking. First, both strain and negative attitudes are latent variables. They are not directly measured, but rather constructed from different proxy measures. Second, since the link between collective strains and terrorism is not direct, a standard regression analysis is not sufficient to test the relationship. My analyses will therefore use path analysis, a more appropriate method for testing Agnew’s model. Path analysis allows for sequential "paths" from variable to variable, mimicking the structure of the GST model in Figure 1, and the proposed path under assessment here, as previously outlined in Figure 2.

First, I examine the bivariate correlation coefficients between variables, displayed in Table 2 below. As we can see, unemployment is not correlated with Public Mood at -0.003 , but has a very strong correlation with Most Important Problem at 0.819 . Poverty exhibits low correlation with Public Mood at 0.197 and low-moderate correlation with Most Important Problem at 0.364 . Then, Public Mood has a moderate correlation with terrorism at -0.536 , while Most Important Problem has low-moderate correlation with terrorism at 0.377 . These relationships are expended upon in a path analysis.

\section{Table 2. Bivariate Correlation Coefficients}

\begin{tabular}{lrrr} 
& \multicolumn{3}{c}{ Dependent Variable } \\
\cline { 2 - 4 } & Mood & Problem & Terror \\
\hline Independent Variable & & & \\
Unemployment & -0.003 & 0.819 & \\
Poverty & 0.197 & 0.364 & \\
Public Mood & & & -0.536 \\
Most Important Problem & & & 0.377 \\
\hline
\end{tabular}


The results of the path analysis on the link between economic strain, negative emotions, and terrorist incidents are presented in Table 3. As expected, unemployment and most important problem have a significant, positive relationship. As unemployment rises, more people consider macroeconomics to be the most important problem. This supports Hypothesis 1b. In contrast, Hypothesis $1 \mathrm{~d}$ is not supported. While the predicted relationship between poverty and the most important problem variable was positive, the path analysis finds a negative, but statistically significant relationship. Essentially, as the poverty rate increases, the percentage of Americans who view macroeconomic issues as the most important issue decreases, which is the opposite of what was theoretically predicted. Macroeconomic public mood is not affected by changes in unemployment, though it is significantly affected by changes in the poverty rate. However, the positive relationship suggests that as poverty rises, public moods towards macroeconomic factors become more liberalistic, meaning that negative emotions and attitudes actually decline. These relationships for the public mood variable do not support either Hypothesis 1a or Hypothesis 1c.

In the second stage of the path analysis, we see that macroeconomic mood is a significant predictor of terrorism in the United States. Specifically, as macroeconomic public mood decreases- meaning emotions become more negative - incidents of terrorism increase. This is consistent with Hypothesis $2 \mathrm{a}$. However, the coefficients for poverty $\rightarrow$ mood and mood $\rightarrow$ terrorism go in opposite directions. Most important problem is also statistically significant when predicting terrorism, though the significance level is not as powerful as mood. Here we can see that there is some suggestion that when macroeconomic factors become more important, that terrorism increases. This supports Hypothesis $2 \mathrm{~b}$. Figure 7 visually represents the significant paths from table 3. 
Table 3 - Path Analysis (One-Tailed Hypotheses)

\begin{tabular}{|c|c|c|c|}
\hline & Deper & dent Var & ables \\
\hline & Problem & Mood & Terror \\
\hline Independent Va & & & \\
\hline & $-4.73 * * *$ & $1.06^{*}$ & \\
\hline tovicy & $(1.56)$ & (.49) & \\
\hline & $11.22 * * *$ & -.59 & \\
\hline 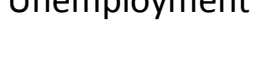 & (1.19) & (.64) & \\
\hline
\end{tabular}

Problem

$.30 *$

Mood

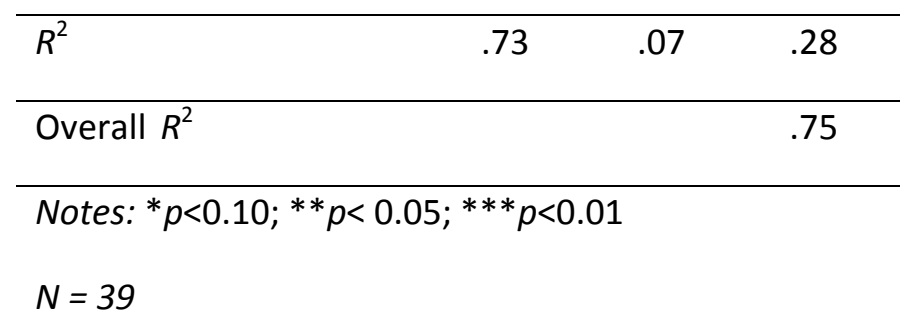

Figure 6. Path Analysis Model

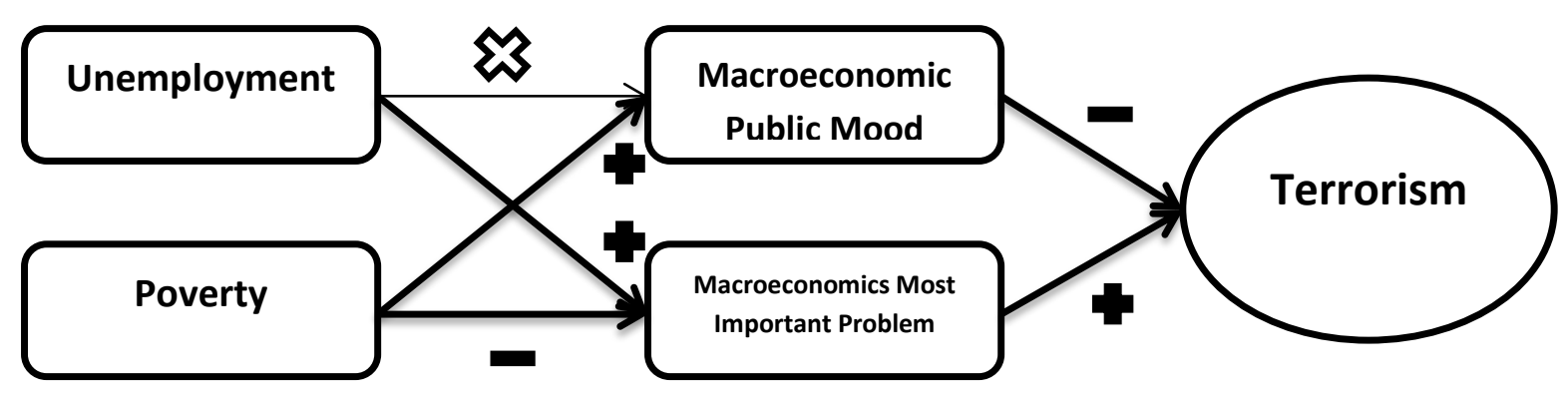




\section{Ancillary Analyses}

An ancillary analysis re-evaluated the path analysis to account for alternate models. First, the path analysis was tested without the Public Mood variable, as shown in Table 4. The results showed strong support for Hypothesis $1 \mathrm{~b}$, meaning that as unemployment increases, the percentage of Americans who view macroeconomics as the most important problem increases. Similarly to the first analysis, Hypothesis 1d was not supported, and even suggests the opposite: that as the poverty rate increases, the number of Americans who view macroeconomics as the most important problem decreases. Hypothesis $2 \mathrm{~b}$ was more strongly supported in this analysis than in the initial estimation. As the number of Americans who view macroeconomics as the most important problem increases, the number of terrorist incidents increases.

Table 4. Path Analysis Excluding Public Mood (One-Tailed Hypotheses)

\begin{tabular}{lcc} 
& \multicolumn{2}{c}{ Dependent Variables } \\
\cline { 2 - 3 } & Problem & Terror \\
\hline Independent Variables & \\
Poverty & $\begin{array}{l}-4.73^{* * *} \\
(1.56)\end{array}$ \\
Unemployment & $\begin{array}{c}11.22^{* * *} \\
(1.19)\end{array}$ \\
Problem & \\
& \\
\hline Note: ${ }^{*} \mathrm{p}<0.10, * * \mathrm{p}<0.05, * * * \mathrm{p}<0.01$ & $(.20)$ \\
$\mathrm{N}=39$
\end{tabular}


Due to the still existent confusion of the relationship between poverty, most important problem, and terrorism, a third analysis was done using path analysis, but excluding poverty and Public Mood as shown in Table 5. This analysis showed the strongest relationship between strain, emotions and attitudes, and terrorism. As unemployment increases, the percentage of Americans who view macroeconomics as the most important problem increases, and as this increases, so do incidents of domestic terrorism in the United States. This supports Hypotheses $1 \mathrm{~b}$ and $2 \mathrm{~b}$, and the larger theoretical hypothesis much more strongly than previous analyses. Note that the statistical significance levels for ancillary analyses have dramatically increased as well.

Table 5. Path Analysis Excluding Public Mood and Poverty (One-Tailed Hypotheses)

\begin{tabular}{lll} 
& \multicolumn{2}{c}{ Dependent Variables } \\
\cline { 2 - 3 } & Problem & Terror \\
\hline Independent Variables & \\
\hline Unemployment & $\begin{array}{c}8.83^{* * *} \\
(.997)\end{array}$ \\
& & \\
Problem & & $.539 * * *$
\end{tabular}

(.212)

Note: ${ }^{*} p<0.10,{ }^{* *} p<0.05,{ }^{* * *} p<0.01$

$\mathrm{N}=39$ 
A final analysis was performed without any intervening variables and tested economic strain against terrorism using a regression analysis, shown in Table 6. The results showed that even without mediators, a statistically significant relationship exists. Unemployment has a strong positive relationship with terrorism, meaning that as unemployment rises, so do incidents of domestic terrorism. Similarly to previous models though, poverty has a strong negative relationship with terrorism in the US. This is the opposite of what was theoretically predicted. The results of this regression show only moderate support for the economic strain-based explanation.

Table 6. Regression Analysis without Intervening Variables (One-Tailed Hypotheses)

\begin{tabular}{lr} 
Variable & $10.97 * * *$ \\
\hline Unemployment & $(3.89)$ \\
& $-16.15 * * *$ \\
Poverty & $(4.65)$ \\
& $173.29 * * *$ \\
Constant & $(42.65)$ \\
\hline $\mathrm{R}^{2}$ & .394
\end{tabular}

Note: $* \mathrm{p}<0.10 ; * * \mathrm{p}<0.05, * * * \mathrm{p}<0.01$ $\mathrm{N}=39$ 


\section{Discussion AND Conclusion}

This research set out to empirically evaluate a relatively new theoretical perspective, Robert Agnew's General Strain Theory of Terrorism, and to offer a possible explanation of varying levels of political violence in the United States. GST postulates that collective strains are likely to result in terrorism through various causal "paths" such as increasing negative emotions, radicalization, fostering the social learning of terrorism, reducing social control and legitimate coping means, and creating a collective orientation and response. I then argue that economic strains act as collective strains, and perform an initial test this model through increasing negative emotions and attitudes, and examining how they may result in domestic terrorism.

To do this, I performed a secondary data analysis of nation-years in the United States. Data was collected on macroeconomic indicators from the Census Bureau and the Bureau of Labor Statistics and on emotions and attitudes towards macroeconomic issues from the public moods dataset and Gallup's most important problem survey. Terrorism data was collected from the Global Terrorism database, and filtered to include only incidents that were considered domestic terrorism without significant doubt.

A path analysis was performed which found some support for the theoretical model. Unemployment was a significant predictor of macroeconomics as the most important problem, but not public mood. Poverty was a significant predictor of public mood and most important problem, however in the opposite direction of what was expected. Public mood and most important problem were both significant predictors of the number of terrorist incidents in the United States, meaning that as emotions and attitudes regarding macroeconomics become more negative, terrorist incidents increase. 
I draw two conclusions from the path analysis results. First: that there is some support of Agnew's GST model, particularly the path from strain through negative emotions to terrorism, even though the relationships tested are far from perfect. Second: that there are a number of problems and limitations that may muddle the results. Some of the relationships are actually the opposite of what was expected theoretically, further confusing the results. The small sample size may be obscuring potentially significant relationships, which can be improved by simply conducting another analysis in the future when more datapoints are available. This analysis also focuses on macro-level factors, and does not account for situational factors, which may be instrumental in pushing groups and individuals from strain to terrorism.

In addition to this, there may be problems with the latent variables not completely or accurately capturing what they are being used to measure. The terrorism variable itself has some issues, namely possible collection problems and changes in criteria. Using data which has been synthesized from multiple collection periods carries this risk. Data collected consistently from the same researchers or organization with the same criteria may yield different results. There are also other ways of measuring terrorism rather than focusing on base number of attacks. Instead, future research could focus on other quantifiable measures such as amount of damage done, number of casualties, and other measures of the 'quality' of terrorism.

It is also possible that negative emotions and attitudes are not being accurately captured. A more direct measure of public emotional state which focuses less on policy issues and more on satisfaction versus frustration and anger would possibly yield different results. The Public Mood variable in particular leaves a big question as to how much 'emotion' is actually being measured versus simply left/right leanings. Furthermore, the relationship between poverty, public mood, and terrorism is the opposite of what is theoretically predicted. It of course makes sense when we 
step back and see that increases in poverty are associated with more liberal attitudes towards government involvement in economics, including taxes and social welfare. It is likely that there is very little in terms of emotion which is represented in this variable. Its predictive power may in fact be reflecting political attitudes more closely associated with a US-specific type of terrorism, specifically right-wing extremism. Essentially, when the mood is more conservative, right-wing extremists are more likely to view the government as their enemy, while other ideologies may not move to this line of thought. These same political cleavages are unlikely to be predictive of terrorism in other cultures.

Based on this analysis, we can conclude that quick, dramatic changes in macro-economic forces such as unemployment may produce the type of strain which may result in terrorism. This is easily related back to both the broader strain theory literature, as well as the frustrationaggression and relative deprivation hypotheses. A sudden increase in unemployment can potentially displace millions of workers who were previously well off. This change may be seen as more unjust, and inflicted by powerful others, and more likely to increase feelings of fear, anger, frustration, and resentment among the collective. These feelings are what Agnew (1992; 2010) argues influences people to turn to deviance and violence.

Poverty increases do not appear to result in terrorism, which is largely consistent with other research evaluating this relationship (Piazza 2006). We can conjecture that poverty is not a dramatic enough change to result in the types of strains which may cause terrorism. Poverty, unlike unemployment tends to be more of a long-term state. It is absolute deprivation, and objective strain, rather than relative deprivation and subjective strain which is associated more with deviance, crime, rebellion, and terrorism (Gurr 1970, Agnew 1992, Agnew 2010). 
Ancillary analyses largely confirm the earlier conclusions of results and limitations. The same Hypotheses were supported, and made stronger with the removal of Public Mood and Poverty, two variables with clear problems in the previous analyses. What this shows is that poverty is not likely a root cause of terrorism in the United States, while unemployment may be. This makes sense when we think about the concepts: poverty is a much more static phenomenon, and individuals typically experience poverty as part of a life course. Poverty is much more of a social reality than unemployment, which represents a dynamic change in socio-economic status and creates much more turmoil in the social environment.

One more interesting point can be conjectured from the descriptive statistics alone, that the overall trend in terrorist incidents has been downward since the 1980s. This is similar to all violent crime in the US. According to the GTD the past decade has been comparatively low in terms of number of terrorist incidents. This leaves us with another question, of whether this trend is the result of post $9 / 11$ policies being effective at deterring violence, part of broader trends of decreasing violence in the United States, or the result of some other, unmeasured factors. It is possible that law enforcement and intelligence agencies have gotten better at stopping terrorist plots before they come to fruition, therefore lowering the count of incidents. It is also possible that the 'quality' of terrorist tactics has improved, so that instead of many 'low quality' attacks, a group only needs one or two 'high quality' attacks in order to accomplish their goals. This would also lower the overall number of incidents. In addition, looking to the broader criminology literature may provide more possible explanations which could help explain this long-term trend.

The results of this study are not strong enough to definitively confirm or refute the principles of General Stain Theory of Terrorism, and should be taken for what they are: a limited test of part of a larger theoretical framework. What we can say from this analysis is that economic 
strains are likely one of many factors which influence terrorism in the United States, and that increasing negative emotions is only one possible path which can lead us there. At the end of the day, this study is not about material gain or macroeconomics, but rather how individuals and groups deal with strain and stressors. This very may well be the case with a more rigorous analysis, or it could be headed in the wrong direction. One thing is certain though, more testing is needed before this theoretical approach can be accepted or refuted. 


\section{REFERENCES}

Agnew, Robert. 1992. "Foundation for a General Strain Theory of Crime and Delinquency." Criminology 30:47-87

Agnew, Robert. 2010. “A General Strain Theory of Terrorism.” Theoretical Criminology, Vol. 14 (2): $131-153$

Black, Donald. 2004. "Terrorism as Social Control." Sociology of Crime, Law, and Deviance. vol. 5:9-18

Burgoon, Brian. 2006. "On Welfare and Terror: Social Welfare Policies and Political-Economic Roots of Terrorism.” The Journal of Conflict Resolution, Vol. 50 (2): 176-203

Caplan, Bryan. 2006. "Terrorism: The Relevance of the Rational Choice Model." Public Choice, Vol. 128, (1/2): 91-107

Cohen, Albert K. 1965. "The Sociology of the Deviant Act: Anomie Theory and Beyond." American Sociological Review 30: 5-14.

Cohen, Albert K. 1997. "An Elaboration of Anomie Theory." The Future of Anomie Theory, Boston: Northeastern University Press.

Department of Homeland Securty. 2009. "Rightwing Extremism: Current Economic and Political Climate Refueling Resurgence in Radicalization and Recruitment." Unclassified Assessment $<$ http://www.fas.org/irp/eprint/rightwing.pdf>

Durkheim, Emile. 1895. "The Rules of Sociological Method" Paris, Fr.

Ehrlich, Paul R. and Jianguo Liu. 2002. "Some Roots of Terrorism." Population and Environment, Vol. 24 (2): 183-192

Federal Bureau of Investigation. 2005. "Terrorism 2002-2005” Department of Justice, Federal Bureau of Investigation, <http://www.fbi.gov/stats-services/publications/terrorism-2002-2005>

Gibbs, Nancy. 12 Feb. 2009. "In Defense of the Recession Blame Game" Time Magazine, <http://www.time.com/time/business/article/0,8599,1878939,00.html>

Gurr, Ted R. 1970. "Why Men Rebel” Princeton, NJ: Princeton University Press

Jost, John T. and David M. Amodio. 2011. Political Ideology as Motivated Social Cognition: Behavioral and Neuroscientific Evidence." Motivation and Emotion 36:55-64

Krueger, Alan B. and Jitka Maleckova. 2003. "Education, Poverty and Terrorism: Is There a Causal Connection?” Journal of Economic Perspectives, Vol. 17 (4): 119-144 
McCauley, Clark and Sophia Moskalenko. 2008. "Mechanisms of Political Radicalization: Pathways Toward Terrorism” Terrorism and Political Violence, Vol. 20 (3): 415-433

Merton, Robert K. 1938. "Social Structure and Anomie". American Sociological Review 3 (5): $672-682$

Piazza, James A. 2006. "Rooted in Poverty? Terrorism, Poor Economic Development, and Social Cleavages." Terrorism and Political Violence 18(1): 159-177

Piazza, James A. 2011. "Poverty, Minority Economic Discrimination, and Domestic Terrorism." Journal of Peace Research, Vol. 48 (3): 339-353

Pape, Robert. 2005. "Dying to Win: The Strategic Logic of Suicide Terrorism.” Ney York: Random House

Przybyla, Heidi "Lawmakers Urge End to Political Rhetoric after Tucson Shootings" 10 Jan. 2011. Bloomberg News Online <http://www.bloomberg.com/news/2011-01-09/lawmakers-urgeend-to-political-rhetoric-after-tucson-shootings.html >

Sageman, Mark. 2004. "Understanding Terror Networks" Philadelphia, PA: The University of Pennsylvania Press.

Sanders, Bernie. 27 June 2012. "The American People are Angry” Huffington Post, <http://www.huffingtonpost.com/rep-bernie-sanders/the-american-people-area_b_1631683.html>

Schinkel, Willem. 2009. "On the Concept of Terrorism." Contemporary Political Theory, Vol. 8 (2): 176-198

Schwartz, Seth, Curtis Dunkel, and Alan Waterman. 2009. "Terrorism: An Identity Theory Perspective.” Studies in Conflict \& Terrorism, Vol. 32: 537-559

Silverstein, Richard. "Death at the Holocaust Museum" 11 June 2009. The Guardian <http://www.guardian.co.uk/commentisfree/cifamerica/2009/jun/11/holocaust-museumshooting-washington>

Sofer, Ken. 2012. Chart: 17 Years After Oklahoma City Bombing, Right Wing Terrorism is Significant Domestic Terror Threat. Thinkprogress.org <http://thinkprogress.org/security/2012/04/19/467384/chart-right-wing-extremism-terror-threatoklahoma-city/?mobile=nc $>$

Stimson, James. 2012. “On the Meaning and Measurement of Mood.” Daedalus 141(4): 23-34

Thorisdottir, Hulda, John T. Jost, Ido Liviatan, and Patrick E. Shrout. 2007.”Psychological Needs and Values Underlying Left-Right Political Orientation: Cross-National Evidence From Eastern and Western Europe.” Public Opinion Quarterly 71(2): 175-203 
Turk, Austin T. 2004. “Sociology of Terrorism.” Annual Review of Sociology, Vol. 30: 271-286

Van Zomeren, M., Spears, R., Fischer, A. H., \& Leach, C. W. (2004). "Put your money where your mouth is! Explaining collective action tendencies through group-based anger and group efficacy." Journal of Personality and Social Psychology, 87:649 - 664

Waldron, Jeremy. 2004. "Terrorism and the Uses of Terror." The Journal of Ethics, Vol. 8 (1): 535

Weeber, Stan C. and Daniel G. Rodeheaver. 2003. "Militias at the Millennium: A Test of Smelser's Theory of Collective Behavior." The Sociological Quarterly, Vol. 44 (2): 181-204

Whitaker, Brian “The Definition of Terrorism” 07 May 2001. The Guardian <http://www.guardian.co.uk/world/2001/may/07/terrorism 
$\underline{\text { Appendix A - Terrorist Groups }}$

\begin{tabular}{|l|l|}
\hline Included Groups & Excluded Groups \\
\hline American Indian Movement & Al-Qa`ida \\
\hline $\begin{array}{l}\text { Americans for a Competent Federal Judicial } \\
\text { System }\end{array}$ & Al-Qa`ida in the Arabian Peninsula (AQAP) \\
\hline Americans for Justice & Anti Shah of Iran \\
\hline Animal Liberation Front (ALF) & Anti-Castro Command \\
\hline Animal Rights Activists & Anti-Castro Group \\
\hline Anti-Abortion Activists & Arabs (suspected) \\
\hline Anti-Environmentalist & Armenian Group \\
\hline Anti-Government Group & $\begin{array}{l}\text { Armenian Secret Army for the Liberation of } \\
\text { Armenia }\end{array}$ \\
\hline $\begin{array}{l}\text { Armed Revolutionary Independence } \\
\text { Movement (MIRA) (suspected) }\end{array}$ & Armenians \\
\hline Army of God & Black September \\
\hline Aryan Nation & Cali Narcotics Cartel \\
\hline Black American Moslems & Croatian Freedom Fighters \\
\hline Black Brigade (United States) & Croatian Liberation Army \\
\hline Black Liberation Army & Croatian Nationalists \\
\hline Black Muslims & Cuban Action \\
\hline Black Panthers & Cuban C-4 Movement \\
\hline Boricua Revolutionary Front & Cuban Exiles \\
\hline Chicano Liberation Front & Cuban Secret Army \\
\hline Chicano Radicals (suspected) & Cypriot \\
\hline Christian Liberation Army (suspected) & Hanafi Muslims \\
\hline $\begin{array}{l}\text { Coalition to Save the Preserves (CSP) } \\
\text { (suspected) }\end{array}$ & Imperial Iranian Patriotic Organization \\
\hline Condor & Iranians (suspected) \\
\hline Continental Revolutionary Army & Irish Republican Army (IRA) \\
\hline $\begin{array}{l}\text { Covenant, Sword and the Arm of the Lord } \\
\text { (CSA) }\end{array}$ & Islamist Extremists \\
\hline Earth First! & Jamaat-al-Fuqra \\
\hline Earth Liberation Front (ELF) & $\begin{array}{l}\text { Justice Commandos for the Armenian } \\
\text { Genocide }\end{array}$ \\
\hline $\begin{array}{l}\text { Earth Liberation Front (ELF),Revenge of the } \\
\text { Trees }\end{array}$ & Kahane Chai (suspected) \\
\hline Earth Night Action Group & $\begin{array}{l}\text { Latin America Anti-Communist Army } \\
\text { (LAACA) }\end{array}$ \\
\hline East Side Action Committee & Lebanese Man \\
\hline Environmental Life Force & Libyan Students \\
\hline & \\
\hline
\end{tabular}




\begin{tabular}{|c|c|}
\hline Environmentalist & Luis Boitel Commandos \\
\hline $\begin{array}{l}\text { Evan Mecham Eco-Terrorist International } \\
\text { Conspiracy (EMETIC) }\end{array}$ & Maccabee Squad and the Shield of David \\
\hline Farm Animal Revenge Militia (FARM) & Macoute sympathizers \\
\hline Fourth Reich Skinheads & Medellin Drug Cartel \\
\hline Fred Hampton Unit of the People's Forces & Mexican Revolutionary Movement \\
\hline $\begin{array}{l}\text { Fuerzas Armadas de Liberacion Nacional } \\
\text { (FALN) }\end{array}$ & Movement for Cuban Justice (Pragmatistas) \\
\hline Gay Liberation Front & Mujahedin-e Khalq (MEK) \\
\hline George Jackson Brigade & $\begin{array}{l}\text { National Front for the Liberation of Cuba } \\
\text { (FLNC) }\end{array}$ \\
\hline $\begin{array}{l}\text { Independent Armed Revolutionary } \\
\text { Commandos (CRIA) }\end{array}$ & National Integration Front (FIN) \\
\hline Individual & Ninth of June Organzation \\
\hline $\begin{array}{l}\text { International Committee Against Nazism } \\
\text { (suspected),Jewish Action Movement } \\
\text { (suspected) }\end{array}$ & Omega-7 \\
\hline Jewish Armed Resistance & Organization Alliance of Cuban Intransigence \\
\hline Jewish Committee of Concern & Otpor \\
\hline Jewish Defenders (suspected) & $\begin{array}{l}\text { Palestine Liberation Organization (PLO) } \\
\text { (suspected) }\end{array}$ \\
\hline Jewish Defense League (JDL) & Palestinians \\
\hline Jewish Direct Action (suspected) & $\begin{array}{l}\text { Popular Front for the Liberation of Palestine } \\
\text { (PFLP) }\end{array}$ \\
\hline Jewish Extremists & $\begin{array}{l}\text { Revolutionary Commandos of the People } \\
\text { (CRP) }\end{array}$ \\
\hline Ku Klux Klan & Secret Cuban Government \\
\hline Left-Wing Militants & Serbian Nationalists \\
\hline May 19 Communist Order & Symbionese Liberation Army (SLA) \\
\hline Mormon Extremist & Tontons Macoutes \\
\hline National Socialist Liberation Front & $\begin{array}{l}\text { Vietnamese Organization to Exterminate } \\
\text { Communists and Restore the Nation } \\
\text { (suspected) }\end{array}$ \\
\hline Neo-Nazi Group & Vietnamese Refugees \\
\hline New Jewish Defense League & Worldwide Organization of Native Taiwanese \\
\hline New World Liberation Front (NWLF) & Young Cuba \\
\hline \multicolumn{2}{|l|}{ Nuclear Liberation Front (suspected) } \\
\hline \multicolumn{2}{|l|}{ Organization 544} \\
\hline \multicolumn{2}{|l|}{ Peoples' Brigade For A Healthy Genetic Future } \\
\hline \multicolumn{2}{|c|}{ People's Liberation Army (United States) } \\
\hline \multicolumn{2}{|l|}{ Phineas Priesthood } \\
\hline \multicolumn{2}{|l|}{ Posse Comitatus } \\
\hline Puerto Rican Armed Resistance & \\
\hline
\end{tabular}




\begin{tabular}{|l|l|}
\hline Puerto Rican Nationalists (suspected) & \\
\hline Puerto Rican Revolutionary Movement & \\
\hline Red Guerilla Family & \\
\hline Republic of New Afrika & \\
\hline Republic of Texas & \\
\hline Revolutionary Cells-Animal Liberation Brigade \\
\hline Save Our Israel Land & \\
\hline Secret Army Organization & \\
\hline Secret Organization Zero & \\
\hline Sons of the Gestapo & \\
\hline Student Radicals & \\
\hline The Jewish Execution with Silence & \\
\hline The Justice Department & \\
\hline The Order (Silent Brotherhood) & \\
\hline The Order II (Bruder Schweigen Strike Force II) \\
\hline The Scorpion & \\
\hline Thunder of Zion & \\
\hline Tribal Thumb & \\
\hline United Freedom Front (UFF) & \\
\hline United Jewish Underground & \\
\hline Universal Proutist Revolutionary Federation & \\
\hline Unknown & \\
\hline Up the IRS, Inc & \\
\hline Weather Underground, Weathermen & \\
\hline White Extremists & \\
\hline Youths of the Star & \\
\hline Zebra killers & \\
\hline
\end{tabular}


$\underline{\text { Appendix B - Dataset }}$

\begin{tabular}{|c|c|c|c|c|c|}
\hline Year & Terror & Unemployment & Poverty & Public Mood & Most Important Problem \\
\hline 1972 & 46 & 5.6 & 11.9 & 62.357 & 24.1135 \\
\hline 1973 & 35 & 4.9 & 11.1 & 58.153 & 38.6482 \\
\hline 1974 & 54 & 5.6 & 11.2 & 58.138 & 56.3478 \\
\hline 1975 & 112 & 8.5 & 12.3 & 56.805 & 59.6859 \\
\hline 1976 & 94 & 7.7 & 11.8 & 57.159 & 55.5344 \\
\hline 1977 & 98 & 7.1 & 11.6 & 55.417 & 45.3159 \\
\hline 1978 & 49 & 6.1 & 11.4 & 54.864 & 59.9662 \\
\hline 1979 & 41 & 5.9 & 11.7 & 53.07 & 50.7661 \\
\hline 1980 & 37 & 7.2 & 13 & 52.978 & 56.3124 \\
\hline 1981 & 34 & 7.6 & 14 & 51.888 & 69.208 \\
\hline 1982 & 46 & 9.7 & 15 & 52.796 & 78.7798 \\
\hline 1983 & 30 & 9.6 & 15.2 & 54.425 & 61.2119 \\
\hline 1984 & 49 & 7.5 & 14.4 & 56.575 & 52.7975 \\
\hline 1985 & 29 & 7.2 & 14 & 56.755 & 44.8276 \\
\hline 1986 & 26 & 7 & 13.6 & 59.937 & 37.4468 \\
\hline 1987 & 22 & 6.2 & 13.4 & 59.114 & 31.3726 \\
\hline 1988 & 14 & 5.5 & 13 & 60.69 & 33 \\
\hline 1989 & 23 & 5.3 & 12.8 & 60.455 & 23.4375 \\
\hline 1990 & 19 & 5.6 & 13.5 & 58.848 & 32.2539 \\
\hline 1991 & 18 & 6.9 & 14.2 & 59.473 & 40.1276 \\
\hline 1992 & 24 & 7.5 & 14.8 & 60.698 & 50.5342 \\
\hline 1993 & . & 6.9 & 15.1 & 61.72 & 46.0902 \\
\hline 1994 & 38 & 6.1 & 14.5 & 58.326 & 22.4404 \\
\hline 1995 & 45 & 5.6 & 13.8 & 59.652 & 29.7101 \\
\hline 1996 & 33 & 5.4 & 13.7 & 58.064 & 31.6416 \\
\hline 1997 & 35 & 4.9 & 13.3 & 59.198 & 21.2364 \\
\hline 1998 & 20 & 4.5 & 12.7 & 57.518 & 16.8942 \\
\hline 1999 & 39 & 4.2 & 11.9 & 57.187 & 11.4541 \\
\hline 2000 & 22 & 4 & 11.3 & 56.638 & 13.814 \\
\hline 2001 & 33 & 4.7 & 11.7 & 56.513 & 21.9932 \\
\hline 2002 & 13 & 5.8 & 12.1 & 58.969 & 25.1848 \\
\hline 2003 & 29 & 6 & 12.5 & 63.991 & 33.5164 \\
\hline 2004 & 8 & 5.5 & 12.7 & 63.357 & 27.6278 \\
\hline 2005 & 16 & 5.1 & 12.6 & 63.738 & 19.2051 \\
\hline 2006 & 5 & 4.6 & 12.3 & 62.403 & 15.1111 \\
\hline 2007 & 9 & 4.6 & 12.5 & 62.592 & 13.587 \\
\hline 2008 & 9 & 5.8 & 13.2 & 63.387 & 39.7258 \\
\hline
\end{tabular}




\begin{tabular}{|l|l|l|c|c|c|}
\hline 2009 & 1 & 9.3 & 14.3 & 66.854 & 52.6982 \\
\hline 2010 & 7 & 9.6 & 15.1 & 66.543 & 48.0118 \\
\hline 2011 & 7 & 8.9 & 15 & 66.035 & 53.2516 \\
\hline
\end{tabular}

